\title{
THE REGULATION USING ENGLISH AS AN INTRUCTIONAL LANGUAGE IN NATIONAL PLUS SCHOOL
}

\author{
Muji Endah Palupi \\ Bahasa Inggris Fakultas Komunikasi dan Bahasa \\ Universitas Bina Sarana Informatika \\ muji.mji@bsi.ac.id
}

APA Citation: Palupi, ME. (2019). The Regulation using English as an Instructional Language in National Plus School. Journal of English Language and literature, 4(2), 10-18. DOI 10.37110/jell.v4i02.75

Received: 07-07-2019

Accepted: 05-08-2019

Published:01-09-2019

\begin{abstract}
This study aims to explore the implementation of use English as an instructional language at school. School regulations made to train student discipline Regulations must be followed by students in the learning process as a benchmark for achieving goals of success. Students need to know positive things in getting used to communicating, writing, and slogans In the modern era it is required to have the ability to speak English. English is an International Language. Western countries play an important role in the development of science and technology. If want to be an expert scientist, linguist, and able to compete with other countries and people have skills in English. In Indonesia, English is also used as a graduation standard in schools, The National plus Schools are combining between The National Curriculum recommended by The National Education Standards Agency, it was adopted from The OECD Country Curriculum or ASEAN Countries. The language of instruction uses English. Schools have goal of creating superior individuals, globally competitive and international capacity.
\end{abstract}

Keywords: Regulation, English, National School Plus

\section{INTRODUCTION}

School regulations are organizational rules that must be adhered to by students, teachers, principals and school members. The goal of school success can be achieved. The role of school environment in the teaching and learning process is also very important in creating a good school environment.

Based on the regulations of The Ministry of Education and Culture (1998: 37), school discipline is a regulation that governs behavior of students while they are in school to create an atmosphere that supports education, school discipline is officially made by the authorities by looking at various considerations that are appropriate to the circumstances and conditions in school environment.

School regulations contain things that are required and things that are prohibited for students while they are in the school environment. There are rules violations carried out by students or other school areas, school has the authority to impose sanctions in accordance with applicable regulations. School discipline is formed to regulate school activities so as to create a polite and healthy atmosphere of school life that guarantees a smooth learning process and a healthy atmosphere of school life.

In Indonesia, The English Language Education curriculum was first made in 1967. English only focuses on junior and senior school, but focused on reading skills. The English curriculum is always updated in the year, the curriculum in 1994, 2004, 2006, and 2013.

In the modern era, English is an International Language as the unifying language of all world societies. Western countries play an important role in the 
development of science and technology. If you want to be an expert scientist, linguist, and able to compete with other countries in the world must understand and people have skills in English.

Along with the times, in the era of globalization people are required to face strong competition countries without geographical limitations. Therefore, individuals are prepared for global competitiveness. On this basic that national and international education school institutions were created.

The use of foreign languages in Indonesia is regulated in Article 29 paragraph 2, Law No 24V2009 concerning Flags, Languages, and National Symbols and National Anthems. In the article, it is stated that foreign languages can be used as a language instruction in educational that supports the foreign language abilities of students. National School Plus is a school that has fulfilled The National Standards of Education in terms of aspects including competency graduates with international characteristics, which include are process of education, education staff, management of school infrastructure and school funding.

According to opinion Marhum, 2009 and Saibah 2009 The National School Plus can develop school culture and school environment that supports the achievement of international standards. Since in 2002, The Coalition School Program Policy has been made.an agreement based on SEAMEO countries. In 2002, 4 Regional Coalition Schools were established which consisted of 2 Elementary Schools and 2 Middle Schools. Coalition schools are divided into two types of schools, namely The Regional Coalition School and The National Coalition School. In the era of globalization demands various changes in various aspects of life. According to Power, 2000; Marhum, 2005 that The Government of The Directorate of Basic Education and Secondary Education Management of The Ministry of National Education has made an education policy that is in accordance with the demands and needs of the community. The Coalition School Program, which is a school that has a network of cooperation between national and international schools in promoting quality and quantity in education. Schools are more dimensioned. How can a National School Plus become an International School?

Regulations use English as an instruction languages have been applied in National Private Schools in Indonesia. Regulations use English from an early age so students can be sustainable and useful after graduating from school. School regulations can train students to discipline. As an increasingly effective benchmark for student learning discipline. School regulations need to be familiarized and introduced in English first. Students need to understand in positive of habituation through communication, writing and slogans. These things are very useful. Habits and repetition of the internalization process to students so that they are familiar with English and students will be more interested and motivated to learn English. Language are main factor in communicating many various aspects of life, namely in the teaching and learning process. In Indonesian National Plus Schools are combine between The National Curriculum recommended by The National Education Standards Agency, but it was adopted from The OECD Country Curriculum or ASEAN Countries, such as The Malaysian and Singapore Curriculums. Teachers are required to take curriculum training and gain knowledge about curriculum design sponsored by Education Directorate. The National Plus School has an important role in improving the ability of Foreign Languages through The International Curriculum

This research was conducted with the aim of exploring implementation of English language education policy at The National Standard plus School. Research uses a qualitative approach. As main techniques in data collection carried out in the main activities such as did researches 
observations, interviews and documentations. Data collection is parallel.

\section{REVIEW OF LITERATURE}

\section{Regulations as a benchmark for achieving success}

Education basically has a purpose to prepare students in an effort to improve quality of life, in school environment of course. There are many students who each have different traits and characters. This is very influential on the level of discipline and order at school. Then it is necessary to form an order to regulate discipline and order of students

Based on The Ministry of Education and Culture (1998: 37), School discipline is a rule that governs the behavior of students during their school to create an atmosphere that supports in education. Regulations must be followed and adhered to by students in the learning process as a benchmark for achieving goals of success. The more students are disciplined with implementation of order, more effective order in the formation of student learning discipline. School discipline is a set of rules or provisions in an organization that includes school components, including students, teachers, principals, and school members.

According to M. Munandar Soelaeman, Basic Social Sciences, (1987:82) with the existence of a code of conduct guaranteeing an orderly, calm life, so that social survival can be achieved. School rules are properly clearly realized, consequently realized and seriously monitored will have the effect of creating an orderly, calm and peaceful atmosphere in the learning community. The regulations that apply everywhere will appear well their existence is monitored and carried out properly School discipline was formed to regulate school activities so that a polite and healthy school life atmosphere was created to ensure the smooth learning process. The purposes of school discipline are (1).Creating feel safe and peaceful atmosphere for all school members (2). Creating a good and healthy atmosphere for all school people (3).Creating a regular condition reflects harmony, balance both in spatial planning, work procedures, social order in school environment (4).Creating a good environment that creates beauty that can be felt by all school people (5). Creating good relations between students and teachers that reflect attitudes and mutual cooperation, openness, mutual help, mutual respect, and mutual tolerance.

According to Elizabeth B. Hurlock, the Life Range, Regulations are made aiming to equip children with guidelines for behaving in certain situations. For example learning rules, this regulation contains what must be done and what students should not do, while studying with existence of school discipline, it will be able to create order in the school so that dynamic conditions can be created which can create harmony and balance of life in the school environment.

A language is a vital tool used for communication and sharing thoughts with other people. Todd 2000:6: stated "A language is a set of signal by which we communicate. Human beings are not the only species to have an elaborate communication system". English Language is an International Language of the world. Based on The history English is a language has dominant power. Language that is recognized as an international communication tool: includes aspects of power that are very strong militarily, politically and economically because English Language is oldest language in the world Britain around 8th century. In addition, English also has a very rapid vocabulary development. The United Kingdom and countries that use English as their National Language are developed countries. The United Kingdom is one of the countries that have most colonies in the world. English is considered very familiar and is widely used in various countries, especially in former British Colony.

According to Cook, 1994; Crystal 1997 
Latin Language has been an International Language because it is very closely related to influence of Romans at that time. Even though Chines Language has most speakers in the world but Chinese still has not been categorized as an international language like as English.

\section{English as a Language of Science and Technology}

English is currently as global language. It is true that it is becoming more dominant throughout the in world. In some countries it is used as mother tongue and other countries as a second language in their schools. In addition, there are many reasons that contribute to increasing of English. For example, it is used for communication between people throughout in the world as a language in modern times. On the other hand, English is language of science and technology. Language of communication people with different cultures.

English as computer language helps aim to communicate with people around the world through technology internet and e-mail. English becomes mandatory in development of science and technology. English has become a necessity that innovation and dissemination of knowledge that is mostly done by western countries such as Britain, The United States and Australia countries. . Based on results study by Dardjowirdjo (2000) show English was studied by 13 million students in Indonesia. There are 100 countries that use English in the education curriculum. English in elementary school will be provision to next level. English is Language Instructional at The National Standard School Plus because in the era of globalization it is very important in education for students, students be able to communicate globally. Students can add insight into language especially in the field of technological science.

\section{Language Policy}

According to Chaer \& Agustina, 2004;
Marhum, 2009a; Wijana \& Rohmadi, 2006, Every Nation has different languages. Politically in Indonesian, there are three important categories of languages, namely: (1).Indonesian National Language Regional Language. (3) Foreign Language. English Language that has been becoming a very popular language used as the language of instruction in formal educations or institutions in Indonesia

In another on opinions Alwasila (1997), Ali (2000), Gunarwan \& Hamid (2000) that the purpose of language policy is to be able to communicate between countries and intranation communication well, without causing social and emotional turmoil that can disrupt stability .

Arthur \& Annamalai (2003), Baldauf \& Luke (1990 stated that. English in Indonesian has the status of a foreign language and is of course only learned in certain formal and nonformal educational institutions and is also only used in certain schools.

\section{English Competition in the Era Globalization}

In era globalization has spread its influence throughout the world. In Indonesia English starting from Science, Technology, Lifestyle, everything starts to advance Impact felt in terms of Education demanded to be able to produce individuals who are globally competitive and of international quality with this recovery, the Government has made various ways to make it happen. The National Standard School Plus education system. That English as language of instruction.

Marhum (2009) stated. The application language policies in formal institutions of The National Schools Plus using English as language of instruction are expected so that students and teachers improve their skills in English. Students in school will get full trust for participants who will attend upcoming international level Science in Olympiad. Requirements for National Schools require use 
of English as a language of instruction especially for in science, mathematics, biology and physics, Information and communication technology. Teachers hold English language training. School has prepared English tutors. Teachers are trained in conversation and use English.

Every teacher and student required use English both during class hours and outside school hours. Student assignments must be in English and sent by email, teacher gives students group assignments and presentations using English as language of instruction. English use in the schools make an effective policy progressive and innovative student. In young generation is expected to future in a challenging era of globalization through as a mastery of science and mastery of English in an active and sustainable manner. Ministry of Education Decree $(2007,42-43)$ recommends that a learning model in English be developed that is in accordance with the characteristics of program implementing school. Learning model are 1. Separately (Parallel) the students are facilitated through supporting activities. English Science and mathematics which must be followed by students carried out in stages and increased English proficiency. 2. Integrated (Integrated) development of student language in an integrated manner in learning using English. Students receive English Mathematics and science subjects together when they receive Mathematics and Natural Sciences lessons in English.

\section{Schools are combining curriculums}

The National School Plus proved to be able to stimulate the character of students to be independent, confident, and creative. The curriculum applied at The National School Plus is The National Curriculum but the adoption of The Curriculum of The OECD countries especially from ASEAN countries.

\section{The government provides financial}

Teachers are required to take part in sponsored curriculum training by The Directorate of Quality Improvement of Educators and Education Personnel. The Ministry of National Education funds teachers to take part in English language skills evaluation activities through the Test of English as International Communication (TOEIC) to improve English language proficiency, teachers take English language courses in cooperation joint at university. Teacher can ask questions about the problems they face at school. In general, lecturers who provide mentoring programs are those who have attended postgraduate programs, especially in OECD countries. The developments of language laboratory facilities are quite complete and representative for students and teachers. The government also provides financial assistance from the central budget and sharing funds from the provincial budget.

Law No. 20 Article 36, an International Primary Curriculum, Paragraph 2 of 2003 concerning The National Education System guarantees freedom of schools to implement a curriculum that is appropriate to needs especially of students and geographical international curriculum. School graduates an International Curriculum will find it easier to continue their studies abroad later. International Curriculum known in Indonesia such as Cambridge International, International Baccalaureate Singaporean Curriculum, and International Primary Curriculum, Each curriculum has advantages and disadvantages. English as the language of instruction in the implementation of education is still more valuable in foreign schools.

\section{Two-way Teaching Method}

The National Plus Schools and International Schools do not merely sell excess foreign language skills but National and International Schools have teaching methods that are not rigid. Learning does not memorize but encourages children to be proactive, have 
leadership, creativity, and good communication so that they have a lot of selling points and attract interest and joined in The ASEAN Economic Community. The world of work requires people who are creative, innovative, confident, have practical abilities. The National School Plus uses a two-way teaching method, in which students are invited to engage in discussion and freedom of speech.

\section{METHODOLOGY}

The researcher chose a qualitative research method for the empirical part of the study as the main aim of this research was to find out how a qualitative approach system. The main technique in collecting data was carried out by the main activities, namely observation, interviews and documentation carried out in parallel and continued with interviews. Qualitative researcher is a study of the broader and more general view of questions; data collection consists of text from participation to theme development.

Miles \& Huberman, 1994; Patton, 2002 in a study a case study approach was used to conduct an investigation into the application of language policies in schools especially with regard to use of English as language of instruction. The research uses descriptive methods systematic analysis collected data Stake (2000: 436) stated, Case studies do not have to be related to the problem of selection of methods but are closely related to what cases will be examined. Cases studied are usually simple or complex. The cases studied can be individuals, groups, children, students, schools or certain organizations. Furthermore, in relation to the case that will be selected in a study. The researcher selected a number of informants in the form of interviews and questions.

\section{FINDING AND DISCUSSIONS}

\section{Research Questions}

a. Why does The National plus School use English as an Instructional language? Why did not use Dutch language? Indonesia was once part of the Dutch colony!

(Informant) We remembered in the past long time ago, the dark history ever experienced by Indonesian Nation. Dutch does not have the status of an International Language. Viewed from the aspect of communication, the influence is not strong enough, so people difficult to interact. English is very broad from various aspects of education level and is very reasonable to prepare to generation of Indonesia to compete globally.

b. What obstacles do schools face using English as the language of instruction? (Informant) In the early years of obstacles faced by students and teachers to apply lessons and substitutes for English is still difficult to apply. Books are written in English. The Regulations policy of using English language in class. Teachers who do not have an English Education background will find it difficult. For example, science teachers and computer technology teachers who have to teach using English may only be $20 \%$. This application may be only $40 \%$ to $50 \%$ and almost evenly distributed throughout Indonesia. Teachers who teach but apply it in Indonesian must be fined. All teaching and learning activities must use English, reducing student graduation rates at announcement of the National Examination. Regional Education Services conduct comprehensive school evaluations at The National Plus level starting from the 
admission of new students, learning systems, facilities, education staff, financial administration and various shortcomings that must be addressed in a gradual and accelerated and planned and ongoing manner

c. What is the role of Indonesian as a National Language in The National plus Schools?

(Informant)

The Regulation use English as language of instruction at National Plus School is not wrong. The purposes are to create superior, globally competitive and international capacity individuals. But love of Indonesian must continue to be developed. The existence of Indonesian Language must be maintained by fostering a positive attitude towards Indonesian. Students use English in Indonesian schools will not shift the function of Indonesian as a National Language as long as people also participate in preserving, caring and being responsive.

\section{$d$. Will student achievement be superior use} foreign curriculum?

(Informant) The Foreign Curriculum has advantages and disadvantages. The Foreign Language Curriculum is indeed considered to still be of more value. Other advantages, National Plus Schools and International Schools have quite different teaching methods. They are able to use international languages and have initiative thinking ways. Schools that teach with creative systems will produce productive leaders. As we all know, the learning process in schools that are not National standard has been thick with learning styles to dictate record and memorize them. While what is needed today is a two-way teaching method, in which students are invited to engage in discussion and freedom of speech.

\section{Recruitment}

In general, National Standard Schools Plus has received ISO status. Every six months must take part in the evaluation. The author discusses the results of research based on questions and research proposed. The research of case base on research The National Standard plus Schools is in Jakarta. The author only examines the National Standard School Plus applied in Indonesia because topic is very interesting to study. The language of instruction in the school is English. The school curriculum used is The National Curriculum and adopted from The Asian State Curriculum so that schools are able to reach the international level

\section{The Quality of National Plus Schools}

Along with development of the Age, in the era of globalization people are required to face intense competition between countries without any geographical limitations. Therefore, individuals who are globally competitive are urgently needed at this time. On that basic, The National and International level schools were created. In Progress the world of education by paying attention to the quality of education system. The quality of graduated who are able to use English as the main benchmark of students in globalization competition

Regulation of The Minister of National Education. All National Plus Schools that The Education system refers to education standards of developed countries that have certain advantages in the education sector so that they have competitiveness in international forums.

The School Curriculum has been 
enriched with quality excellence and quality from the member countries of the Organizational for Economic Co-operation and Development (OECD). The National Education Standards are divided into 3 categories namely: Standard Schools, Independent Schools and International Standard Schools.

\section{The Characteristics of National Plus Schools}

School have received of international recognition in quality and tested results in various aspects of the quality of education abroad. This is evidenced by the results of certification and accreditation with good predicate.

In terms of the teaching-learning process, schools are role models for other schools in developing noble character, noble character, superior personality, leadership and innovators.

\section{Indonesian as National language will} not be forgotten

Even though National Plus School uses English as a substitute language, the role of Indonesian will not be forgotten. However, the portion of Indonesian language usage has been reduced; this problem can be overcome by applying the use of Indonesian in Indonesian lessons. Optimization is implemented by applying a learning system that is practical and has little theory. Because basically, students are more understanding when the learning system is practiced so students can also apply their use of Indonesian language properly and in daily life in the situation of using Indonesian as a National Language. English contribution in field of education, English continues to spread for communication between people around the world.

In modern times English is the language of science and technology computer languages that help to communicate with people around the world through technology such as e-mail, internet, books. All use English. In modern era at education field, English language education institutions that contribute throughout the world. English is dominant in the field of education in scientific research at universities and institutes. By knowing and mastering English, it will increase more value especially when continuing education and looking for work easily. The purposes of using English as International language Students can communication in another people in the world, students easily to share ideas and information in conversation. Mastering English also increases the opportunity to get a good job abroad.

\section{Discussion}

\section{School rules train student discipline}

In the school environment, of course many students have different traits and characters. This affects the level of discipline and order in the school. More students are disciplined and more effective student learning. Regulations using English as a language of substitution have been applied in national private schools in Indonesia. Habits and repetitions provide a process of internalization to students so that they are familiar with English. Students will be more interested and motivated to learn English. Students discipline using English early so useful after graduating from school. What achievements have The 
National School plus achieved in developing an English language program?

In the global world of National Schools Plus can be a bridge so students have a plus in terms of language, knowledge and technology to compete in the era of globalization

\section{CONCLUSION}

The use of English as the language of instruction and learning at The National Standard School Plus is due to the goal of creating superior, globally competitive and

\section{REFERENCES}

ANPS. (2011, May 25). About Us: Associations of National Plus School. Retrieved from September 25, 2011, Associations of National Plus School Bertaraf International: http://anps-bi.org I

Agustin, Y. 2011. Kedudukan Bahasa Inggris Sebagai Bahasa Penggantar Dalam Dunia .Pendidikan. Deiksis, 3.(04),354364.

Crystal, D (2003). English as a Global Language. Cambridge: Cambridge. University Press

Efendi, A.N (2010). Sekolah Nasional Plus

Gerbang Kompetisi Global. Jakarta.: Tempo

ElizabethB. Hurlock, Perkembangan Suatu . internationally capable individuals. But the love of Indonesian as a National Language must continue to be developed. Indonesian must also be maintained by fostering a positive attitude towards Indonesian by community. The use of English Language in Indonesian schools will not shift the function of Indonesian as long as people love their country. "That intelligent people are people who can use certain languages".

The National School Plus gets benefits of English language instruction and flexibility. Because competition people who can use certain languages".

PendekatanSepanjangRentangKehidu pan, Jakarta:.Erlangga).

Hardini, I. (2012:183). Strategi Pembelajaran Terpadu

Munandar, M and Soelaeman, Ilmu Sosial . Dasar, Bandung: Eresco, 1987, h., 82)

Nugraheni, Aninditya. Sri. 2014. Bahasa Sebagai Akar Kepribadian. Lentera Kreasindo. Yogyakarta http://awirawan.multiply.com/journal/it $\mathrm{em} / 1$ IBetapa Pentingnya Bahasa Inggris Saat Ini

KEMDIKBUD: (1998:37). Tata Tertib Sekolah, .Jakarta: 13 Departemen Pendidikan dan .Kebudayaan, 